\title{
Gender Participation of Tribal People in Tripura in Different Livestock Activities
}

\author{
K. Jamatia ${ }^{1}$, M. N. Ray ${ }^{1}$, S. Payeng ${ }^{1}$, L. Bora ${ }^{1 *}$, M. Johari ${ }^{1}$, N. K. Roy ${ }^{1}$ and D. Roy ${ }^{2}$ \\ ${ }^{1}$ Department of Extension Education, College of Veterinary Science, AAU, Khanapara, India \\ ${ }^{2}$ Department of Livestock Production and Management, College of Veterinary Science, \\ $A A U$, Khanapara, India \\ *Corresponding author
}

\begin{tabular}{|l|}
\hline \multicolumn{1}{|l}{} \\
\hline Ke y w o r d s \\
Tripura, Deb \\
Barma, Jamatia, \\
Tribal women, \\
Livestock activities \\
\hline Article Info \\
\hline $\begin{array}{l}\text { Accepted: } \\
\text { 07 March } 2020 \\
\text { Available Online: } \\
\text { 10 April } 2020\end{array}$ \\
\hline \hline
\end{tabular}

\section{A B S T R A C T}

The current study was taken up in the state of Tripura and the two districts of Sepahijala and Gomati were purposely selected for the purpose which is mostly inhabited by Deb Barma and Jamatia tribes, respectively. Four villages from each district were selected and a total of 100 respondents (tribal women) were selected by Snowball sampling method, making the total sample size 200. A total of 17 activities were considered for assessment of the gender participation of tribal people of Tripura in different activities under livestock enterprises. High participation of tribal women was observed in livestock related activities like collection of eggs (94.00 per cent), preparation of feed for animals (89.00 per cent), feeding \& watering of birds ( 87.00 per cent), feeding and watering of animals ( 87.00 per cent), cleaning of animal shed (83.00 per cent), maintenance of bird shed (82.00 per cent), care of sick animals ( 82.00 per cent), care of new born animals ( 82.00 per cent), care of health condition of animals (77.00 per cent), bathing of animals (72.00 per cent). The corresponding figures for Jamatia women were 94.00 per cent, 92.00 per cent, 94.00 per cent, 67.00 per cent, 60.00 per cent, 88.00 per cent, 65.00 per cent, 65.00 per cent and 51.00 per cent respectively. They also performed jointly the activities like selling of animal at market age, maintenance of animal shed, collection of fodder and grazing of animals, etc.

\section{Introduction}

Agriculture in India is still a family enterprise where family participates as a unit and share of women is half of the human resource in farming. Rural Indian women are extensively involved in agricultural and related farming activities. However, participation and extent of their involvement in farming differ under different agro-production systems. The mode of female participation in agricultural production varies with land owning status of farm households. Their roles range from managers to landless labourers. Irrespective of their size of land holding livestock and poultry find a place in every rural household for subsidiary income generation, family consumption of animal protein and other socio-cultural and religious needs. Historically, Tripura was an ancient kingdom 
ruled by 184 Maharajas of Manikya dynasty and after Independence of our country it became a part of India where there are as many as 19 tribes. All of them keep different livestock traditionally for income generation, their own household consumption and other socio-religious necessities. Therefore, it is quite justified to analyse the pattern of participation of male and female tribal people in Tripura in different livestock activities. Under this back drop, the present study was undertaken with the sole objective of assessment of the gender participation of Tribal People of Tripura in different activities under livestock enterprises.

\section{Materials and Methods}

There are 19 recognised tribes in Tripura out of which Deb Barma, Reang, Chakma and Jamatia are considered as major tribes as per their population size. Deb Barma and Jamatia tribes were purposely selected for the study. The two districts viz. Sepahijala and Gomati were purposely selected as the former is predominantly inhabited by Deb Barma tribals whereas the latter is predominantly inhabited by Jamatia tribes. Four villages from each district were selected and a total of 100 respondents (tribal women) were selected by Snowball sampling method. Thus a total of 200 respondents, taking 100 from each of the two tribes constitute the sample size. An inventory was prepared in consultation with a few village headmen where as many as 22 livestock rearing activities were incorporated.

Later it was pretested in 20 non-sample respondents to assess its reliability and validity. The frequency of participation of male and female tribal people of the above mentioned two tribes were ascertained by asking direct question to respondents. They were asked whether they perform a particular activity alone or with their husbands. Data were collected personally by the researchers from all the respondents during March and April, 2019. The collected data were processed, tabulated and frequency and percentages were calculated.

\section{Results and Discussion}

Table 1 revealed the preponderance of Deb Barma women in activities like "collection of eggs" (94.00 per cent), "preparation of feed for animals" (89.00 per cent), "feeding \& watering of birds"(87.00 per cent), "feeding and watering of animals" (87.00 per cent), "cleaning of animal shed"(83.00 per cent), "maintenance of bird shed"(82.00 per cent), "care of sick animals"(82.00 per cent), "care of new born animals"( 82.00 per cent), "care of health condition of animals" (77.00 per cent), "bathing of animals" (72.00 per cent). The corresponding figures for Jamatia women were 94.00 per cent, 92.00 per cent, 94.00 per cent, 67.00 per cent, 60.00 per cent, 88.00 per cent, 65.00 per cent, 65.00 per cent and 51.00 per cent respectively.

Joint participation of men and women in Deb Barma tribe was noticeably high in activities like "selling of animal at market age" (79.00 per cent), "maintenance of animal shed" (62.00 percent), "collection of fodder" (47.00 per cent) and "grazing of animals" (46.00 per cent). The relative figures of joint participation for Jamatia men and women were 82.00 per cent, 84.00 per cent, 82.00 per cent and 78.00 per cent.

The activities which witnessed higher lone participation of Jamatia men than Deb Barma men were "selling of bird product, by-product and produces" (92.00 per cent) and "selling of animal product and produces" (84.00 per cent). However, activity like collection of fodder was jointly done by men and women in both the tribes i.e. Deb Barma (47.00 per cent) and Jamatia (82.00 per cent). It is a generally held view that field activities are 
mainly done by men and indoor activities are done by women. But in the present case both male and female participate in collection of fodder. The woman folk accompanied their man and sometimes man also accompanied woman. It was set in their mind that together they could collect more fodder for their animals in shorter period.

The slight difference in percentage in these two tribes might be due to the fact that the respondents from Jamatia tribe do not go for other diversified income generating activities whereas the respondents of Deb Barma tribe engage in diversified activities and hence could only contribute to the above findings. This finding is in line with the finding of Sujeetha et al., (2017) who conducted a study in Nilgiris district of Tamil Nadu on tribal women and found that almost all the activities of dairying are performed by tribal women. They also revealed that women actively perform their roles in collecting fodder for animal (4.48 mean score).

A glance at Table 1 exhibited that in preparation of feed for animal, women folk engaged in very large number compared to men in both the tribes i.e. Deb Barma (89.00per cent) and Jamatia (92.00per cent). It goes without saying that feed preparation for livestock being an indoor activity attracted the participation of exclusively women folk who during performing other household chores also do prepare animal feed by efficiently utilizing their time. On other hand, their male counterpart often goes for the outdoor activities and found it difficult to take part in feed preparation. However, the respondents of these two tribes do not differ significantly.

This result is in line with the finding of Deb Barman (2017) who found out that majority of women are involved in preparing feeds and product processing (73.75per cent).
Grazing of animals was mainly practiced jointly by men and women in both the tribes i.e. Deb Barma (46.00 per cent) and Jamatia (78.00 per cent) as depicted in Table 1. Together they go for grazing animals in the field. This might be due to the fact that in absence of men, women go for grazing and vice-versa. Women mainly grazed small animals and go for tethering of pigs whereas large animals were grazed by men. Deb Barma tribe had less participation in grazing probably due to diversified or mixed farming system adopted by them. Their lower herd size, higher income from other sources might be the contributing factors for such finding. The above finding was similar with the finding of Wahab et al., (2016) who found that 20 per cent respondents contribute to the caring of animal, 25per cent feeding, 18per cent watering-grazing of animal.

As displayed in Table 1 feeding and watering of livestock came under the dominance of solely women in both the tribes i.e. Deb Barma (87.00 per cent) and Jamatia (67.00 per cent). Since women folk are considered as person for taking care of animals and their kids. So, these activities are kept aside by men with a hope on their women. There was a huge difference between Deb Barma and Jamatia in percentage of participation in feeding and watering of animals because majority of Deb Barma tribe were having smaller herd size than the respondents from Jamatia tribe, which might be attributed to the engagement of the male in other activities leaving livestock for women. The above finding was in line with the finding of Narmatha et al., (2009) who revealed cent per cent participation of women in feeding and watering, Rathod et al., (2011) also found similar finding that respondents participated in feeding the animals ( 87 per cent), Deb Barman (2017) also found that 44.50 per cent women participated in cleaning and feeding of pig. 
Table.1 Frequency distribution of gender participation of the tribal people in different activities under livestock enterprises

\begin{tabular}{|c|c|c|c|c|c|c|c|}
\hline \multirow[t]{3}{*}{$\begin{array}{l}\text { SI. } \\
\text { No }\end{array}$} & \multirow[t]{3}{*}{ Activities } & \multicolumn{2}{|c|}{ Women alone } & \multicolumn{2}{|c|}{ Man alone } & \multicolumn{2}{|c|}{$\begin{array}{c}\text { Jointly(Men \& } \\
\text { Women) }\end{array}$} \\
\hline & & Deb Barma & Jamatia & $\begin{array}{c}\text { Deb } \\
\text { Barma }\end{array}$ & Jamatia & $\begin{array}{l}\text { Deb } \\
\text { Barma }\end{array}$ & Jamatia \\
\hline & & Frequency $(\%)$ & $\begin{array}{l}\text { Frequency } \\
(\%)\end{array}$ & Frequency $(\%)$ & Frequency $(\%)$ & $\begin{array}{c}\text { Frequency } \\
(\%)\end{array}$ & $\begin{array}{l}\text { Frequency } \\
(\%)\end{array}$ \\
\hline 1 & $\begin{array}{l}\text { Collection of } \\
\text { Fodder }\end{array}$ & $\begin{array}{c}33 \\
(33.00)\end{array}$ & $\begin{array}{c}9 \\
(9.00)\end{array}$ & $\begin{array}{c}11 \\
(11.00)\end{array}$ & $\begin{array}{c}9 \\
(9.00)\end{array}$ & $\begin{array}{c}47 \\
(47.00)\end{array}$ & $\begin{array}{c}82 \\
(82.00)\end{array}$ \\
\hline 2 & $\begin{array}{l}\text { Preparation of feed } \\
\text { for animal }\end{array}$ & $\begin{array}{c}89 \\
(89.00)\end{array}$ & $\begin{array}{c}92 \\
(92.00)\end{array}$ & $\begin{array}{c}4 \\
(4.00)\end{array}$ & $\begin{array}{c}2 \\
(2.00)\end{array}$ & $\begin{array}{c}5 \\
(5.00)\end{array}$ & $\begin{array}{c}6 \\
(6.00)\end{array}$ \\
\hline 3 & Grazing of animals & $\begin{array}{c}13 \\
(13.00)\end{array}$ & $\begin{array}{c}2 \\
(2.00)\end{array}$ & $\begin{array}{c}12 \\
(12.00)\end{array}$ & $\begin{array}{c}7 \\
(7.00)\end{array}$ & $\begin{array}{c}46 \\
(46.00)\end{array}$ & $\begin{array}{c}78 \\
(78.00)\end{array}$ \\
\hline 4 & $\begin{array}{c}\text { Feeding and } \\
\text { watering of animals }\end{array}$ & $\begin{array}{c}87 \\
(87.00)\end{array}$ & $\begin{array}{c}67 \\
(67.00)\end{array}$ & $\begin{array}{c}2 \\
(2.00)\end{array}$ & $\begin{array}{c}2 \\
(2.00)\end{array}$ & $\begin{array}{c}11 \\
(11.00)\end{array}$ & $\begin{array}{c}31 \\
(31.00)\end{array}$ \\
\hline 5 & $\begin{array}{l}\text { Cleaning of animal } \\
\text { shed }\end{array}$ & $\begin{array}{c}83 \\
(83.00)\end{array}$ & $\begin{array}{c}60 \\
(60.00)\end{array}$ & $\begin{array}{c}3 \\
(3.00)\end{array}$ & $\begin{array}{c}2 \\
(2.00)\end{array}$ & $\begin{array}{c}13 \\
(13.00)\end{array}$ & $\begin{array}{c}36 \\
(36.00)\end{array}$ \\
\hline 6 & Milking of animal & $\begin{array}{c}24 \\
(24.00)\end{array}$ & $\begin{array}{c}30 \\
(30.00)\end{array}$ & $\begin{array}{c}11 \\
(11.00)\end{array}$ & $\begin{array}{c}7 \\
(7.00)\end{array}$ & $\begin{array}{c}16 \\
(16.00)\end{array}$ & $\begin{array}{c}20 \\
(20.00)\end{array}$ \\
\hline 7 & $\begin{array}{l}\text { Selling of animal } \\
\text { product and } \\
\text { produces }\end{array}$ & $\begin{array}{c}8 \\
(8.00)\end{array}$ & $\begin{array}{c}1 \\
(1.00)\end{array}$ & $\begin{array}{c}48 \\
(48.00)\end{array}$ & $\begin{array}{c}84 \\
(84.00)\end{array}$ & $\begin{array}{c}39 \\
(39.00)\end{array}$ & $\begin{array}{c}2 \\
(2.00)\end{array}$ \\
\hline 8 & $\begin{array}{l}\text { Maintenance of } \\
\text { animal shed }\end{array}$ & $\begin{array}{c}32 \\
(32.00)\end{array}$ & $\begin{array}{c}7 \\
(7.00)\end{array}$ & $\begin{array}{c}6 \\
(6.00)\end{array}$ & $\begin{array}{c}7 \\
(7.00)\end{array}$ & $\begin{array}{c}62 \\
(62.00)\end{array}$ & $\begin{array}{c}84 \\
(84.00)\end{array}$ \\
\hline 9 & $\begin{array}{l}\text { Selling of animal at } \\
\text { market age }\end{array}$ & $\begin{array}{c}5 \\
(5.00)\end{array}$ & $\begin{array}{c}0 \\
(0.00)\end{array}$ & $\begin{array}{c}16 \\
(16.00)\end{array}$ & $\begin{array}{c}18 \\
(18.00)\end{array}$ & $\begin{array}{c}79 \\
(79.00)\end{array}$ & $\begin{array}{c}82 \\
(82.00)\end{array}$ \\
\hline 10 & Bathing of animals & $\begin{array}{c}72 \\
(72.00)\end{array}$ & $\begin{array}{c}51 \\
(51.00)\end{array}$ & $\begin{array}{c}8 \\
(8.00)\end{array}$ & $\begin{array}{c}10 \\
(10.00)\end{array}$ & $\begin{array}{c}17 \\
(17.00)\end{array}$ & $\begin{array}{c}17 \\
(17.00)\end{array}$ \\
\hline 11 & Care of sick animals & $\begin{array}{c}82 \\
(82.00)\end{array}$ & $\begin{array}{c}65 \\
(65.00)\end{array}$ & $\begin{array}{c}1 \\
(1.00)\end{array}$ & $\begin{array}{c}3 \\
(3.00)\end{array}$ & $\begin{array}{c}17 \\
(17.00)\end{array}$ & $\begin{array}{c}30 \\
(30.00)\end{array}$ \\
\hline 12 & $\begin{array}{l}\text { Care of new born } \\
\text { animals }\end{array}$ & $\begin{array}{c}82 \\
(82.00)\end{array}$ & $\begin{array}{c}65 \\
(65.00)\end{array}$ & $\begin{array}{c}0 \\
(0.00)\end{array}$ & $\begin{array}{c}2 \\
(2.00)\end{array}$ & $\begin{array}{c}18 \\
(18.00)\end{array}$ & $\begin{array}{c}30 \\
(30.00)\end{array}$ \\
\hline 13 & Collection of eggs & $\begin{array}{c}94 \\
(94.00)\end{array}$ & $\begin{array}{c}94 \\
(94.00)\end{array}$ & $\begin{array}{c}0 \\
(0.00)\end{array}$ & $\begin{array}{c}0 \\
(0.00)\end{array}$ & $\begin{array}{c}5 \\
(5.00)\end{array}$ & $\begin{array}{c}2 \\
(2.00)\end{array}$ \\
\hline 14 & $\begin{array}{l}\text { Feeding \& watering } \\
\text { of birds }\end{array}$ & $\begin{array}{c}87 \\
(87.00)\end{array}$ & $\begin{array}{c}94 \\
(94.00)\end{array}$ & $\begin{array}{c}2 \\
(2.00)\end{array}$ & $\begin{array}{c}1 \\
(1.00)\end{array}$ & $\begin{array}{c}10 \\
(10.00)\end{array}$ & $\begin{array}{c}0 \\
(0.00)\end{array}$ \\
\hline 15 & $\begin{array}{l}\text { Selling of bird } \\
\text { product, by-product } \\
\text { and produces }\end{array}$ & $\begin{array}{c}9 \\
(9.00)\end{array}$ & $\begin{array}{c}2 \\
(2.00)\end{array}$ & $\begin{array}{c}49 \\
(49.00)\end{array}$ & $\begin{array}{c}92 \\
(92.00)\end{array}$ & $\begin{array}{c}41 \\
(41.00)\end{array}$ & $\begin{array}{c}6 \\
(6.00)\end{array}$ \\
\hline 16 & $\begin{array}{l}\text { Maintenance of bird } \\
\text { shed }\end{array}$ & $\begin{array}{c}82 \\
(82.00)\end{array}$ & $\begin{array}{c}88 \\
(88.00)\end{array}$ & $\begin{array}{c}2 \\
(2.00)\end{array}$ & $\begin{array}{c}2 \\
(2.00)\end{array}$ & $\begin{array}{c}15 \\
(15.00)\end{array}$ & $\begin{array}{c}6 \\
(6.00)\end{array}$ \\
\hline 17 & $\begin{array}{l}\text { Care of health } \\
\text { condition of } \\
\text { animals }\end{array}$ & $\begin{array}{c}77 \\
(77.00)\end{array}$ & $\begin{array}{c}51 \\
(51.00)\end{array}$ & $\begin{array}{c}0 \\
(0.00)\end{array}$ & $\begin{array}{c}1 \\
(1.00)\end{array}$ & $\begin{array}{c}23 \\
(23.00)\end{array}$ & $\begin{array}{c}46 \\
(46.00)\end{array}$ \\
\hline
\end{tabular}


The cleaning of animal shed was mainly done by women alone in both the tribes i.e. Deb Barma (83.00 per cent) and Jamatia (60.00 per cent). Since time immemorial women folk have been contributing in indoor activities under livestock enterprises in traditional way as their part of life. So it was obvious to get such finding from the present study. In that case, Deb Barma women displayed higher participation because they have less land holding and mostly follow tethering and pacca floor rearing system. So to avoid any outbreak of diseases and foul odour they had to clean the shed regularly. Similar pattern of finding was noticed in the study conducted by Rathod et al., (2011), Wahab et al., (2016) and Debbarman (2017). In the present study milking of animal was mainly done by women alone in both the tribes i.e. Deb Barma (24.00 per cent) and Jamatia (30.00 per cent). The parents are always concerned about their children's health. So, it was necessary for both the parents to participate in milking. But in this present study, women's participation was higher. The difference between two tribes was because of the fact that Jamatia tribes were having large herd size and land holding so they could rear large animals like cattle, buffalo, etc. So, it was prudent to say that Jamatia would be having more participation in milking of animals. The finding was corroborated by those reported by Rathod et al., (2011) and Ahmad, T.I. (2014).

Selling of animal product and produces were mainly done by men in both the tribes i.e. Deb Barma (48.00 per cent) and Jamatia (84.00 per cent). It might have been apprehended that engagement of women in this activity could earn the risk as women were likely to be cheated or dumbed in market place. Jamatia tribe was more in number in this activity because women had to look after the house and their children. The finding was in line with the finding of Kalai and Devarani (2018) who conducted a study in Charilam block of Sepahijala District of Tripura on 120 respondents of which 60 numbers were women (30 tribal and 30 non-tribal) and 60 numbers were man (30 tribal and 30 nontribal) found that adequate percent of men were more than women in the indicators input in productive decision, purchase, sale and transfer of assets and speaking in public.

Maintenance of animal shed was mainly done jointly by men and women in both the tribes i.e. Deb Barma (62.00per cent) and Jamatia (84.00per cent) as presented in Table 1 The maintenance of animal shed requires time and labour and therefore joint participation makes it easy. It was observed that Jamatia tribe had higher participation due to the fact that their herd size was larger. So, obviously it needed longer time and more labour force. Similar pattern of finding was observed in the study conducted by Narmatha et al., (2009) who in their study found that farm women contributed in livestock farm activities in addition to their routine household duties and in which management activities were performed by them.

A perusal of data from Table 1 revealed that selling of animal at market age was mainly done jointly by men and women in both the tribes i.e. Deb Barma (79.00 per cent) and Jamatia ( 82.00 per cent). When a livestock is taken care of by women it is considered her asset and have full right for decision making regarding selling of animal at market age. Women also are engaged in small livestock rearing like pig and goat go for selling their animal in market. Likewise, the large animals are taken care of by men and are considered as his asset. In the same way, they too go for selling their animals in market. So, it may be concluded that both men and women participate in selling animals at market age. Jamatia had higher participation in selling of animals at market age, this might be due to their larger herd size. This result is supported 
by finding of Arshad et al., (2013) who revealed that rural women were engaged in a wide range of livestock management practices such as marketing of animals, brooding and breeding (64.2 per cent), marketing of animal produce (60per cent).

The aspect of bathing of animals was mainly taken up by women alone in both the tribes i.e. Deb Barma (72.00 per cent) and Jamatia (51.00 per cent). The very reason for the above finding could be their awareness of health condition of animal and their knowledge level and education level. In this activity larger number of respondents from Deb Barma participated due to higher literacy rate. The above finding was in line with the finding of Arshad et al., (2013) who found that rural women were engaged in a wide range of livestock management practices like bathing of animals (26.7per cent). It was noticed in the current study that care of sick animals was mostly done by women alone in both the tribes i.e. Deb Barma (82.00 per cent) and Jamatia (65.00 per cent). Women generally become mother, care taker, and overall in-charge of the household, therefore besides taking care of the family members they also look after and supervise the ailing animals. It was seen in Deb Barma, majority of this tribal women are engaged in this activities, because they are educated, skilled in scientific approach and considered this task as their duty. This finding was in line with Deb Barman (2017) who found that most of the works were performed by both male and female in majority of the activity like deworming and medication (49.75 per cent). Bharali (2016) also reported that rural women participated independently in different livestock activities such as care of sick animal (74.58 per cent) and taking care in vaccination of livestock (70.83 per cent).

It was observed in Table 1 that care of new born animals was mostly done by women alone in both the tribes i.e. Deb Barma (82.00per cent) and Jamatia (65.00per cent). The very reason for this finding could be attributed to their down to earth nature towards animals and awareness and knowledge level. Deb Barma witnessed high participation compared to Jamatia because Deb Barma were well educated and knew how to deal with the situation in better way. This finding is in line with the finding of Arshad et al., (2013) who found that rural women were engaged in a wide range of livestock management practices such as caring of diseased animals (82.5per cent) and calf rearing (67.5per cent).

Women are predominantly engaged in collection of eggs in both the tribes i.e. Deb Barma (94.00per cent) and Jamatia (94.00per cent) and in feeding \& watering of fowl in both the tribes i.e. Deb Barma (87.00per cent) and Jamatia (94.00per cent). This work was regarded as feminine job, so men do not engage themselves in these activities and also attributed to their perception of this work as their duty irrespective of remunerative value. This finding is in line with the finding of Kemprai (2009) who found that women had high level of physical involvement viz., 'feeding' (41.11 per cent), 'management of chicks' (37.77 per cent) and 'disease management' (31.11 per cent). Selling of fowl and its produce, product and by-product was mainly done by men alone in both the tribes i.e. Deb Barma (49.00 per cent) and Jamatia (92.00 per cent) as depicted in Table 1 The explanation for this finding is similar to that of selling of animal at market age.

The same table also revealed dominant participation of women in maintenance of fowl shed in both the tribes i.e. Deb Barma (82.00per cent) and Jamatia (88.00per cent) and in care of health condition of animals in

both the tribe i.e. Deb Barma (77.00per cent) and Jamatia (51.00per cent). The explanation is 
same with the care of new born animals. This result born out with similar finding of those Paul et al., (2015)

In conclusion it may be projected that tribal women in Tripura had high participation in livestock related activities like collection of eggs, preparation of feed for animals, feeding and watering of birds, feeding and watering of animals, cleaning of animal shed, maintenance of bird shed, care of sick animals, care of new born animals, care of health condition of animals, bathing of animals and milking of animals etc. They also performed jointly with their male counterpart in activities like selling of animal at market age, maintenance of animal shed, collection of fodder and grazing of animals, etc. However, the difference of participation of women belonging to the two tribes in Tripura in livestock activities might be due to the fact that the Deb Barma tribe was involved in diversified activities in contrast to the Jamatia tribe having engagement only in agriculture and livestock.

\section{References}

Ahmad, T.I. (2014). Role of rural women in livestock management: socio economic evidences from diverse geographical locations of Punjab (Pakistan). Ph.D. Thesis, Geography, Université Toulouse le Mirail - Toulouse II, HAL Id: tel$00933784 \quad$ https://tel.archivesouvertes.fr/tel-00933784.

Arshad, S., Muhammad, S. and Ashraf, I. (2013). Women's participation in livestock farming activities. The Journal of Animal \& Plant Sciences, 23(1): 304308.

Bharali, R. (2016). Economic empowerment of rural women of Assam through agro- based enterprises. Ph. D Thesis, Assam Agricultural University, Jorhat, Assam, India.

Debbarman, C. (2017). Role of indigenous pig for sustainable livelihood security of tribal farmers in North-East India. Ph. D Thesis, C.V.Sc., Assam Agricultural University, Khanapara, Guwahati, India.

Kalai, K. and Devarani, L. (2018). Gender differences in agricultural empowerment: A cross-cultural study in Tripura. Indn. Res. J. Ext. Edu., 18 (3).

Kemprai, S. (2009). A study on role of tribal farm women in farming in Karbi Anglong district, Assam. M.Sc. Thesis, Assam Agricultural University, Jorhat, Assam, India.

Narmatha, N., Uma, V., Arun, L., and Geetha, R. (2009). Level of participation of women in livestock activities. J. Vet. Ani. Sci.5: 4-8.

Paul, P., Meena, B.S., Singh, A. and Wani, S.A. (2015). Gender participation in integrated farming system in Tripura, India. Asian J. Dairy \& Food Res., 34 (1): 59-62.

Rathod, P.K., Nikam,T.R; Landge, S., Vajreshwari, S. and Hatey, A.(2011) Participation of rural women in dairy farming in Karnataka. Indn. Res. J. Ext. Edu.11 (2).

Sujeetha, T.N. and Anamica, M. (2017). Role performance of Nilgiris tribal women in animal husbandry operations. International J. of Agri. Sci. and Res., 7(2): 529-532.

Wahab, P., Asharf, M.Q., Shamas-Uddin, M. A (2016). Role of women in livestock management in rural areas of district Attock, Pakistan. J. Innov. Res. and Dev. 1(1): 20-24.

\section{How to cite this article:}

Jamatia, K., M. N. Ray, S. Payeng, L. Bora, M. Johari, N. K. Roy and Roy, D. 2020. Gender Participation of Tribal People in Tripura in Different Livestock Activities. Int.J.Curr.Microbiol.App.Sci. 9(04): 518-524. doi: https://doi.org/10.20546/ijcmas.2020.904.062 